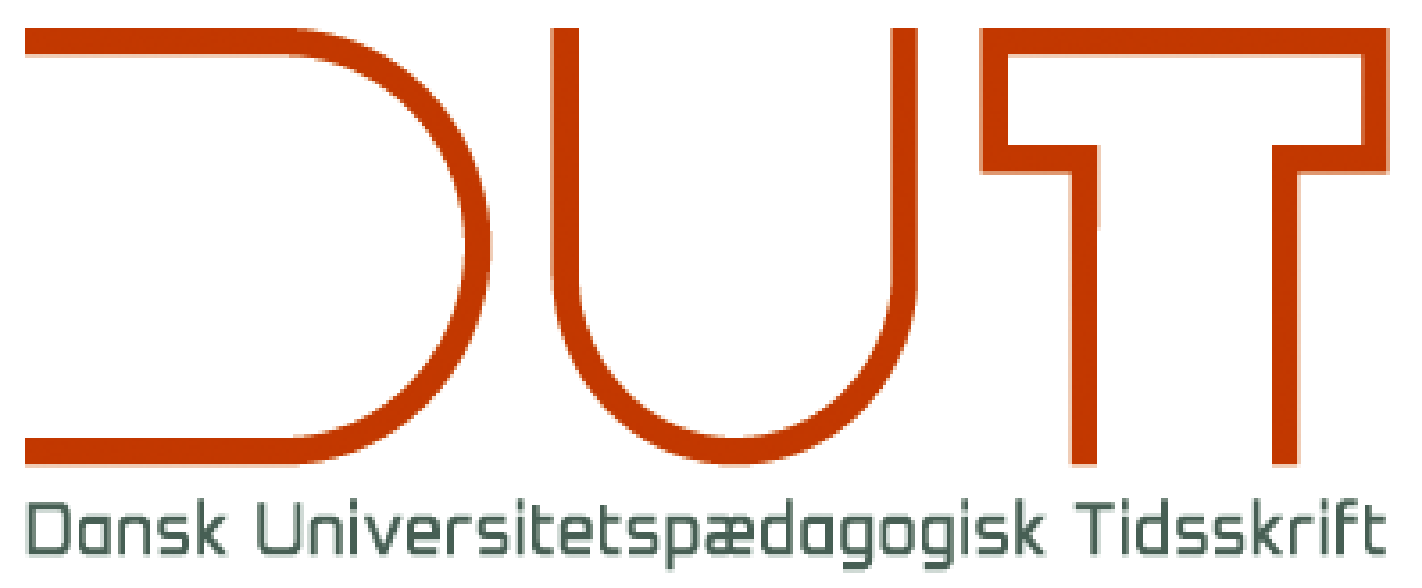

Læringsrum

Årgang 14 nr. 27 / 2019

Titel

God vejledning - af specialer, bacheloropgaver og projekter (2. udgave)

Forfattere

Niels Hansen

Sidetal

$200-201$

Udgivet af

Dansk Universitetspædagogisk Netværk, DUN

URL

> http://dun-net.dk/

Betingelser for brug af denne artikel

(C) Copyright
Denne artikel er omfattet af ophavsretsloven, og der må citeres fra den. Følgende betingelser skal dog være opfyldt:

- Citatet skal være i overensstemmelse med "god skik"

- Der må kun citeres „i det omfang, som betinges af formålet“

- Ophavsmanden til teksten skal krediteres, og kilden skal angives ift. ovenstående bibliografiske oplysninger.

DUT og artiklens forfatter 


\section{God vejledning - af specialer, bacheloropgaver og projekter (2. udgave)}

Skrevet af Lotte Rienecker, Gitte Wichmann-Hansen og Peter Stray Jørgensen

Udgivet 2019 på Samfundslitteratur, 290 sider, ISBN: 9788759329719

Anmeldt af Niels Hansen ${ }^{\mathrm{a}, 1}$

anstitut for Ledelse, Aarhus Universitet

For undervisere ved universiteter og professionshøjskoler udgør vejledning ofte en betydelig del af jobbet, og selv om der udbydes kurser inden for området, er mange nok overladt til selv at skulle finde inspiration og viden om vejledningen. Her er der god hjælp at hente i bogen 'God vejledning', der her i foråret er kommet i en ny og revideret udgave fra Samfundslitteratur.

To af forfatterne er gamle kendinge; Lotte Rienecker og Peter Stray Jørgensen, som står bag en betydelig del af de bøger, der er udgivet på dansk omkring emner som opgaveskrivning og vejledning. Til denne nye udgave er der tilkommet en ny medforfatter; Gitte WichmannHansen fra Aarhus universitet, som forsker i og afholder kurser om netop vejledning.

\section{Konkrete råd og anvisninger}

Bogen indeholder anvisninger på alle vejledningens facetter, både omkring vejledningsforløbet og forholdet mellem vejleder og studerende. Det er min opfattelse, at der er sket en udvikling fra førsteudgaven til denne 2. udgave. I den nye udgave er der råd og anvisninger på, hvordan vejledningssamtalen kan gennemføres, hvor jeg oplever, at 1. udgaven mere beskrev hvad og hvilke elementer, der indgår.

Eksempler på dette er, hvilke spørgsmål der typisk vil indgå i vejledningens forskellige faser. Et andet eksempel er anvisningen på de forskellige typer spørgsmål, vi kan udfordre de studerende med; konkretiserende-, undersøgende- og udfordrende spørgsmål. Denne metodik er klart med til at løfte vejledningen til et højere niveau.

\section{Systematisk gennem vejledningens faser}

Bogen gennemgår systematisk alle vejledningens faser og facetter startende med, hvad vejledning egentligt er samt forventningsafstemningen mellem den studerende og vejleder. Herunder behandles også balancen mellem den studerendes og vejleders opgaver og ansvar.

Det er min opfattelse, at en del vejledere viger tilbage fra at vejlede om det tekstmæssige og de studerendes skriveform. Den opfattelse havde jeg også selv, indtil jeg læste 1. udgaven og deltog i et vejledningskursus. Vi må dog erkende, at så længe den tekstmæssige fremstilling af en opgave eller afhandling er en del af evalueringsgrundlaget, så bør det også være en del af vejledningen. Her giver et stort afsnit omkring dette emne gode anvisninger på, hvorledes man kan gribe det an.

\footnotetext{
${ }^{1}$ Kontakt: nh@mgmt.au.dk
} 
Erfarne vejledere ved udmærket hvad 'feedback' er, men læser man det godt 20 sider lange kapitel om feedback, kan det nok være, at man får sine begreber udvidet en hel del. Hvem af os har lige været helt skarpe på at adskille feedback i forhold til fagligt indhold, form og udførelse, processer og modtager?

\section{Kollektiv vejledning}

Fremdriftsreformen, omprioriteringsbidrag og andre effektiviseringstiltag på uddannelsesinstitutionerne presser os alle, og giver os mindre tid til de enkelte opgaver. Vi er således nødt til at effektivisere vores tid og helst uden, at det går ud over kvaliteten af vores arbejde. Her har jeg i de sidste par år haft glæde af at gennemføre en del af vejledningen som kollektiv vejledning - ikke som erstatning, men som et supplement til den individuelle vejledning. Afsnittet om kollektiv vejledning giver god anvisning på, hvad der egner sig til denne form, og hvorledes det kan gennemføres.

Nye afsnit omkring vejledning på litteratur, dobbeltrollen som både vejleder og bedømmer, samt tværfaglige opgaver og projekter er alle relevante emner, der ligeledes behandles.

Fra egne erfaringer og samtaler med kolleger ved jeg, at vejledningsrollen pludseligt kan udvikle sig til konfliktløser, når de studerende i de grupper, man vejleder, ikke kan enes om niveau, retning, arbejdsindsats etc. Her er der god hjælp at hente i et nyt udførligt afsnit om gruppevejledning, der både giver råd om samarbejdsaftaler, der skal forhindre konfliktens opståen, samt nogle råd såfremt konflikten så rent faktisk opstår.

\section{En ressource for nye såvel som erfarne vejledere}

Kapitlerne i bogen starter med et afsnit, som kort fortæller, hvad kapitlet handler om. Efter selve kapitlets tekstsider afsluttes med kapitlets 'highlights'. Denne form giver rigtig god mening for mig, da jeg sjældent læser denne type bog fra start til slutning. Her kommer intro og highlights til at fungere som en 'appetizer', så man får lyst til lige at snuppe dette kapitel også.

Nu har jeg skrevet denne anbefaling - kan jeg så også anbefale bogen? Ja det kan jeg. For nye vejledere betragter jeg bogen som et 'must', der vil afklare mange af de usikkerhedsområder, en ny vejleder står overfor. Ligeledes er bogen et rigtigt godt sted at søge information, hvis erfarne vejledere ønsker at videreudvikle sig og bringe deres vejledning op på et højere stade. 